\title{
Determination of Effects of Location of Loading on Mechanical Properties of Different Cultivars of Yam (Dioscorea Spp) Tubers
}

\author{
Ijabo, O. J, Irtwange, S. V and Uguru, $\mathrm{H}^{*}$
}

Department of Agricultural and Environmental Engineering, University of Agriculture, Makurdi, Nigeria

\author{
DOI: $10.36348 /$ sjeat.2019.v04i11.001 \\ | Received: 02.10.2019| Accepted: 09.10.2019| Published: 16.11.2019 \\ *Corresponding author: Uguru Hilary
}

\section{Abstract}

In this work, the effects of storage period on nine mechanical properties and moisture content of stored yam (Dioscorea spp) tubers were investigated. The mechanical properties of whole intact yam tubers of three yam (Dioscorea spp) cultivars in various treatments including: four levels of storage time at 75 days interval spanning 225 days, and four levels of loading positions namely at the head, middle, tail and vertical, were presented in this study. Mechanical compression tests were performed on three different cultivars namely: Ogoja, Gbangu and Agbo-yian. The results of the study showed that the force at bio-yield point, force at peak point, force at breaking point, and energy at bio-yield point during compression test in general is significantly higher in the middle of the tuber than other locations. The value for bio-yield force range from $1059 \mathrm{~N}$ for Agbo-yian to 4,500 N for Gbangu. So for safe stacking of Dioscorea alata in containers and stacks $1059 \mathrm{~N}$ is safe while for Dioscorea rotundata 4,500 N would be adequate. Energy follows the same pattern as forces. Results obtained from this study will be helpful in the design and fabrication of yam tubers harvesting and handling machines.

Keywords: Mechanical properties, yam tubers, location of loading, bio-yield point.

Copyright @ 2019: This is an open-access article distributed under the terms of the Creative Commons Attribution license which permits unrestricted use, distribution, and reproduction in any medium for non-commercial use (NonCommercial, or CC-BY-NC) provided the original author and source are credited.

\section{INTRODUCTION}

Yam, Dioscorea spp, is a semi-perishable class of food due to its relatively high moisture [1] and carbohydrate contents. Yam provides around 110 calories per 100 grams of produce. It contains mainly carbohydrates with little amounts of proteins, lipids and vitamins [2]. An understanding of the map of mechanical characteristics of yam tubers over its body may improve planting, harvesting, handling and processing equipment design and manufacturing. The edible yam (Dioscorea spp.) tubers are important staple food for millions of people in tropical countries especially in West Africa [3]. The tubers of various species of Dioscorea spp constitute one of the stable carbohydrate foods for the people in many tropical countries [4]. Many different forms and cultivars of the edible yam species are available in different areas and it is likely that they differ not only in composition and nutritional values [5] but also in mechanical properties.

Armando et al., [6] after studying two varieties of yam (Dioscorea alata): Diamante 22 and Picode Botella concluded that mechanical damage to yam tubers is the major limiting factor of the automation of its production and increased productivity. The cell wall matrix of yam plays an important role in controlling the mechanical behaviour of cell walls. Plant tissue can be viewed in engineering theory as composite material, which contains a solid phase, i.e. cell walls that variously partitions a fluid phase, i.e. living protoplasm in parenchyma [7].

The ever increasing importance of agricultural produce such as yam (Dioscorea spp) together with the complexity of modern technology for their production, processing and storage need a definite knowledge of mechanical properties at bio-yield point, peak and rupture point of these crops, It therefore becomes very necessary to understand the distribution of these properties over the body of tubers to maximize efficiency and the quality of the final products. With this increasing application, little information is available on the basic engineering properties of these materials, particularly in developing country like Nigeria. For example little is known of the mechanical properties of Ogoja, Gbangu and Agbo-yian yam cultivars grown in the Benue River Basin of Nigeria. Besides most of the previous studies were conducted using cut out sections of other yam cultivars for their studies, which may not be obtainable under real 
handling and storage conditions. Therefore, the objective of this study is to determine the mechanical properties of yam tubers at different locations of loading, namely head, middle, and tail and along the vertical axis using quasi-static loading.

\section{MATERRIALS AND METHOFDS}

Yams

Freshly harvested yam tubers (Ogoja, Gbangu and Agbo-yain) used for the research were obtained from Gboko area of Benue state, Nigeria. The yams were planted in heaps and about 700 heaps in one hectare of land. Fertilizer (NPK 15-15-15) application was manually done, at the rate of $50 \mathrm{~kg} / \mathrm{ha}$ in the third month after planting. Prior to experiment, the yam tubers were cleaned by soft brush to remove the adhering soil and other foreign materials.

\section{Experimental Design}

The experimental design for the statistical analyses followed two-treatment effects which are, loading position and cultivar in a Completely Randomized Design involving three observations per experimental unit. The indices would comprise of four mechanical properties at each of bio-yield point, peak or ultimate point and c) rupture or breaking point. The mechanical properties are force, deformation, strain and energy giving a total of 12 indices however, since strain is a normalized deformation given as percentage with respect to diameter of the tuber, it will be omitted and only nine properties would be used making 81 (9 indices $\mathrm{x} 3$ yam cultivars $\mathrm{x} 3$ replications $=81$ ) observations.

\section{Determination of the Mechanical Properties (Compression Test)}

The compression test was performed on the whole intact yam tubers to determine the force and deformation at bio-yield point, force at peak point and at rupture for the three different yam cultivars. The test was conducted in the materials testing laboratory of the National Centre for Agricultural Mechanization
(NCAM) Ilorin, Kwara State, using the $50 \mathrm{kN}$ capacity universal testing machine (Testometric, series 500-532) in February 2016.

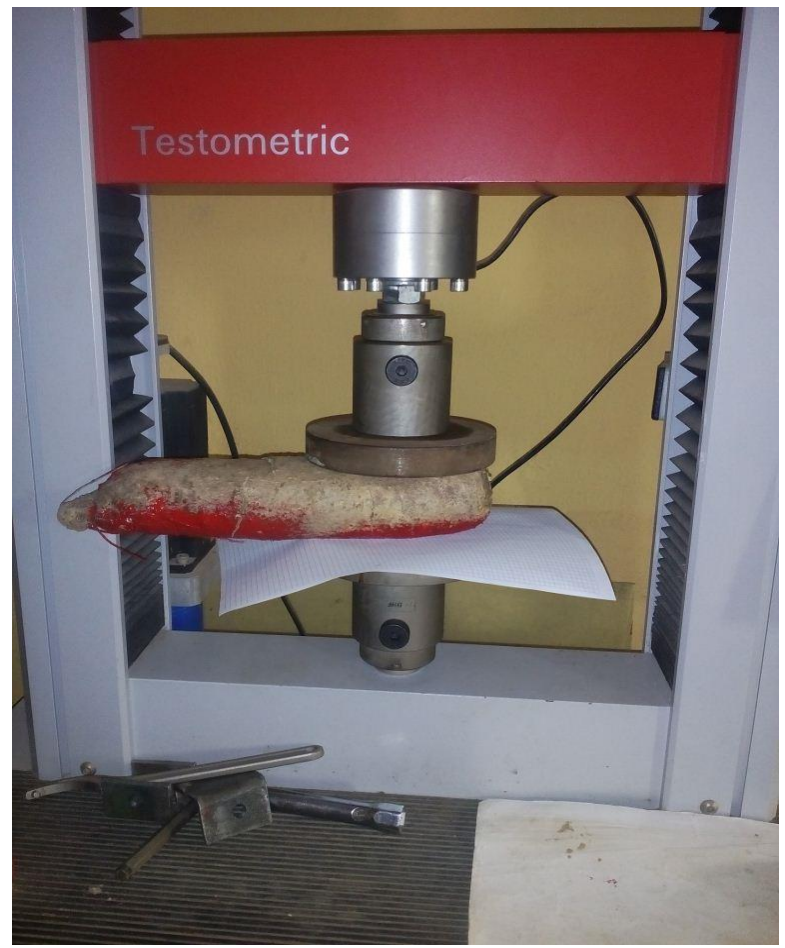

Fig-1: Yam tuber under test

Each yam tuber was placed in the machine under the flat compression tool (Figure-1), ensuring that the centre of the tool was in alignment with the peak of the curvature of the yam tuber. The test speed was set at $50 \mathrm{~mm}$ per minute [8] and the yam tuber is loaded to the point of rupture. Force-deformation curve was produced automatically by the universal testing machine. Each test was carried out using three (3) yam tubers. As quasi compression of the yam tuber progressed, a forcedeflection curve was plotted automatically by the Universal Testing Machine (Figure-2), in relation of the sample to the compression, up to the rupture point.

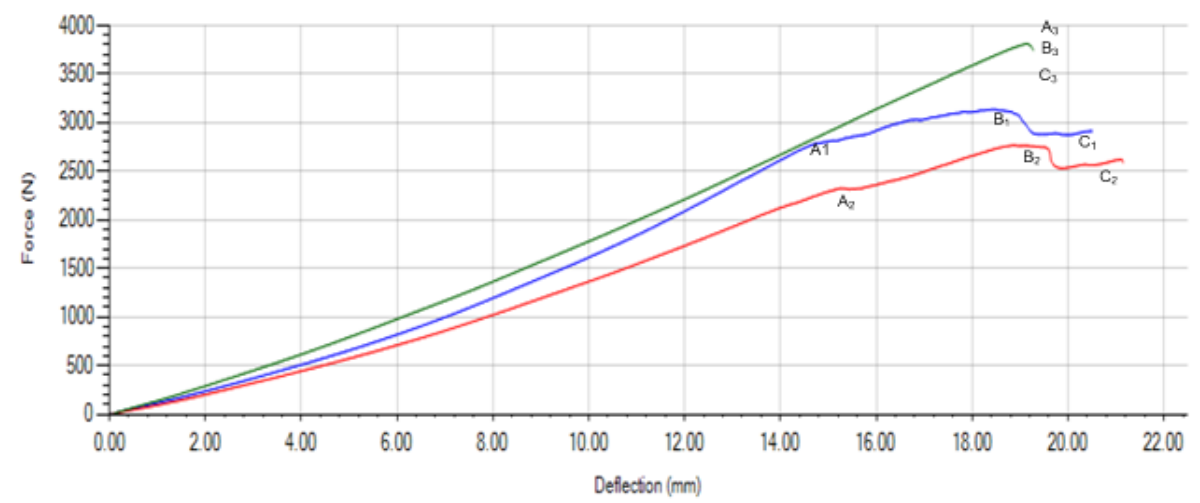

- Test 1 - Test2 - Test 3

Fig-2: A typical Force - deformation curve of Agboyian yam tuber under compression loading 
ljabo et al., Saudi J Eng Technol, Nov. 2019; 4(11): 447-451

$\mathrm{A}=$ Elastic limit, which is equivalent to the force at bioyield point

$\mathrm{B}=$ Ultimate compressive strength, which is equivalent to the force at peak

$\mathrm{C}=$ Breaking point strength, which is equivalent to force at rupture

Subscripts 1,2 , and 3, = the replications

\section{RESULTS AND DISCUSSIONS}

Figure-2 shows a typical compression loaddeformation curve generated for a tuber sample under compression test. The three points of interest on the curve are labeled A, B and C which is bio-yield point, peak and rupture (breaking) point respectively. For each point the machine generates force, deformation, energy and strain making 12 mechanical properties per a sample under test. Consequently, the machine tabulates the mechanical properties which are 1) Bio-yield force, $\mathrm{N}, 2$ ) Force at peak point, N, 3) Force at breaking (or rupture) point, $\mathrm{N}, 4)$ Deformation at bio-yield point, $\mathrm{mm}, 5$ ) Deformation at peak point, $\mathrm{mm}, 6$ ) Deformation at rupture point, mm, 7) Strain at bio-yield point, \%, 8) Strain at peak point, \%, 9) Strain at rupture, \%, 10) Energy at bio-yield point, Nm, 11) Energy at peak Nm, and 12) Energy at rupture, Nm. Data collected from compression tests were subjected to ANOVA using the SPSS 110 software package and shown in Table-1. Treatment means were compared using Duncan's New Multiple Range Test $(\mathrm{P}<0.05)$ and the results displayed in Table-2.

Table-1: Analysis of variance of nine mechanical properties in three yam cultivars

\begin{tabular}{|l|l|l|l|l|l|l|l|}
\hline $\begin{array}{l}\text { Yam } \\
\text { cultivar }\end{array}$ & source & Df & $\begin{array}{l}\text { Force at Bio- } \\
\text { yield pt. }\end{array}$ & $\begin{array}{l}\text { Force at } \\
\text { peak pt. }\end{array}$ & $\begin{array}{l}\text { Force at } \\
\text { breakpt }\end{array}$ & $\begin{array}{l}\text { Energy at Bio- } \\
\text { yield Pt. }\end{array}$ & $\begin{array}{l}\text { Strain at peak } \\
\text { point }\end{array}$ \\
\hline Gbangu & $(\mathrm{S})$ & 3 & $6.63 \mathrm{E}-10^{*}$ & $1.20 \mathrm{E}-10^{*}$ & $3.16 \mathrm{E}-08^{*}$ & $0.0049883^{*}$ & $5.18 \mathrm{E}-08^{*}$ \\
\hline Ogoja & $(\mathrm{S})$ & 3 & $3.15 \mathrm{E}-07^{*}$ & $2.48 \mathrm{E}-11^{*}$ & $4.73 \mathrm{E}-10^{*}$ & $0.028755092^{*}$ & $1.48 \mathrm{E}-13^{*}$ \\
\hline Agboyian & $(\mathrm{S})$ & 3 & $9.1359 \mathrm{E}-05^{*}$ & $9.16 \mathrm{E}-06^{*}$ & $8.28762 \mathrm{E}-05^{*}$ & $0.003964944^{*}$ & $0.02288718^{*}$ \\
\hline
\end{tabular}

\begin{tabular}{|l|l|l|l|l|l|l|}
\hline Yam cultivar & Yam section & Df & Energy at braking pt & Strain at bio-yield pt & Strain at break pt & Energy at peak pt \\
\hline Gbangu & $(\mathrm{S})$ & 3 & $0.0092019^{*}$ & $1.81 \mathrm{E}-08^{*}$ & $2.15 \mathrm{E}-07^{*}$ & $0.00457462^{*}$ \\
\hline Ogoja & $\mathrm{S})$ & 3 & $0.003725968^{*}$ & $7.46 \mathrm{E}-10^{*}$ & $3.7 \mathrm{E}-11^{*}$ & $0.007926079 *$ \\
\hline Agboyian & $\mathrm{S})$ & 3 & $5.85 \mathrm{E}-10^{*}$ & $0.001155212^{*}$ & $0.038780631^{*}$ & $1.89 \mathrm{E}-06^{*}$ \\
\hline
\end{tabular}

* =Significant on the level of 5\%, ns= non significant; $\mathrm{S}=$ Yam Section

\section{Force and Energy Studies}

Figures 3, 4, 5 and 6 show the influence of yam loading section on the forces of intact Agbo-yian, Gbang $u$ and Ogoia yam tubers. In the figures the force at bio-yield point, force at peak point and the force at breaking point, are invariably highest at the middle part of the yam tuber during compression, contrary to the cut out yam section results of Judith [9] which identified the head as being capable of withstanding the highest force. This is analogous to a pipe on the ground being stronger than when it stands alone. The ground provides some buffering effects as do the head and tail sections. So this difference may be due to error in using cut out parts on the part of Judith [9] or instrumentation of either of the investigators and needs further enquiry. For the purpose of piling yams in transportation and storage, the bio-yield force of tubers should be the guiding criterion in design or containers.

Force at peak is higher than that of rupture for Agbo-yian while it tallies with peak force for both Gbangu and Ogoja, which both belong to Dioscorea rotundata. In all peak force has a wide range from 1059 $\mathrm{N}$ for Agboyian to 4,500 N for Gbangu and for practical purposes it would be preferred to view them in terms of $D$. alata and $D$. rotundata. Therefore, for processing a force of $1059 \mathrm{~N}$ should be used for D. alata and 4,500 $\mathrm{N}$ for D. rotundata. Vertical force is lowest for $D$. rotundata cultivars and intermediate for Agbo-yian which again is D. alata cultivar. Vertical force is in many instances lower than other values. Since most stacking of yams as at present is done horizontally, this would be noted for future use. 
ljabo et al., Saudi J Eng Technol, Nov. 2019; 4(11): 447-451

Table-2: The mean effect of sections on selected mechanical properties of tubers of three yam cultivars

\begin{tabular}{|c|c|c|c|c|c|c|c|c|c|c|c|c|c|c|c|}
\hline \multirow{2}{*}{$\begin{array}{l}\text { Ya } \\
\text { m } \\
\text { Cult } \\
\text { ivar }\end{array}$} & \multirow[t]{2}{*}{$\begin{array}{l}\text { Secti } \\
\text { on }\end{array}$} & \multicolumn{2}{|c|}{$\begin{array}{l}\text { Bio-yield } \\
\text { point }\end{array}$} & \multicolumn{2}{|c|}{$\begin{array}{l}\text { Force at peak } \\
\text { point }\end{array}$} & \multicolumn{2}{|c|}{$\begin{array}{ll}\text { Force } & \text { at } \\
\text { breaking Pt }\end{array}$} & \multicolumn{2}{|c|}{$\begin{array}{l}\text { Bio-yield } \\
\text { energy }\end{array}$} & \multicolumn{2}{|c|}{ Strain at peak Pt. } & \multicolumn{2}{|c|}{$\begin{array}{l}\text { Energy at } \\
\text { breaking pt. }\end{array}$} & \multicolumn{2}{|c|}{$\begin{array}{l}\text { Strain at Bio- } \\
\text { yield pt. }\end{array}$} \\
\hline & & $\bar{x}$ & $\mathbf{S}$ & $\overline{\bar{x}}$ & $\mathbf{S}$ & $\overline{\bar{x}}$ & S & $\bar{x}$ & $\mathbf{S}$ & $\overline{\bar{x}}$ & $\mathbf{s}$ & $\overline{\bar{x}}$ & $\mathrm{~s}$ & $\overline{\bar{x}}$ & $\mathbf{s}$ \\
\hline $\begin{array}{l}A g b \\
o-\end{array}$ & Head & 985 & $\begin{array}{l}348 . \\
716\end{array}$ & $\begin{array}{l}1190 . \\
33\end{array}$ & $\begin{array}{l}239.2 \\
33\end{array}$ & 1152 & $\begin{array}{l}217.41 \\
4\end{array}$ & $\begin{array}{l}4.97 \\
5\end{array}$ & $\begin{array}{l}2.18 \\
8\end{array}$ & 12.335 & 3.283 & 8.379 & $\begin{array}{l}1.86 \\
8\end{array}$ & $\begin{array}{l}10.5 \\
15\end{array}$ & 2.152 \\
\hline yian & $\begin{array}{l}\text { Midd } \\
\text { le }\end{array}$ & 2028 & $\begin{array}{l}459 . \\
157 \\
\end{array}$ & 2380 & $\begin{array}{l}329.8 \\
47 \\
\end{array}$ & 2224 & 133.72 & $\begin{array}{l}8.71 \\
4 \\
\end{array}$ & $\begin{array}{l}1.83 \\
0 \\
\end{array}$ & 14.840 & 1.817 & 23.710 & $\begin{array}{l}10.3 \\
57\end{array}$ & $\begin{array}{l}9.27 \\
3\end{array}$ & 1.876 \\
\hline & Tail & 1046 & $\begin{array}{l}84.8 \\
71 \\
\end{array}$ & 1059 & $\begin{array}{l}68.60 \\
8 \\
\end{array}$ & 1059 & 68.608 & $\begin{array}{l}6.10 \\
2 \\
\end{array}$ & $\begin{array}{l}0.69 \\
5 \\
\end{array}$ & 13.895 & 0.771 & 6.332 & $\begin{array}{l}0.35 \\
6 \\
\end{array}$ & $\begin{array}{l}13.6 \\
43 \\
\end{array}$ & 0.780 \\
\hline & $\begin{array}{l}\text { Verti } \\
\text { cal }\end{array}$ & $\begin{array}{l}1776 . \\
667 \\
\end{array}$ & $\begin{array}{l}288 . \\
791\end{array}$ & $\begin{array}{l}1897 . \\
667 \\
\end{array}$ & $\begin{array}{l}459.6 \\
71 \\
\end{array}$ & $\begin{array}{l}1852 \\
.33 \\
\end{array}$ & $\begin{array}{l}409.34 \\
3 \\
\end{array}$ & $\begin{array}{ll}19.4 \\
35 \\
\end{array}$ & $\begin{array}{l}4.69 \\
4 \\
\end{array}$ & 10.013 & 2.000 & 23.588 & $\begin{array}{l}11.3 \\
85 \\
\end{array}$ & $\begin{array}{l}9.24 \\
7 \\
\end{array}$ & 0.737 \\
\hline $\begin{array}{l}\text { Gba } \\
n g u\end{array}$ & Head & $\begin{array}{l}1967 . \\
667 \\
\end{array}$ & $\begin{array}{l}815.7 \\
28 \\
\end{array}$ & $\begin{array}{l}4268 . \\
667 \\
\end{array}$ & $\begin{array}{l}676.8 \\
31 \\
\end{array}$ & $\begin{array}{l}4261 . \\
33\end{array}$ & $\begin{array}{l}664.54 \\
8 \\
\end{array}$ & $\begin{array}{l}10.6 \\
95 \\
\end{array}$ & $\begin{array}{l}6.73 \\
1 \\
\end{array}$ & 27.704 & 1.962 & 35.944 & $\begin{array}{l}9.27 \\
6 \\
\end{array}$ & $\begin{array}{l}23.2 \\
57 \\
\end{array}$ & 9.19 \\
\hline & $\begin{array}{l}\text { Midd } \\
\text { le }\end{array}$ & 2479. & $\begin{array}{l}1449 . \\
687\end{array}$ & $\begin{array}{l}4492 . \\
667 \\
\end{array}$ & 993.3 & $\begin{array}{l}4448 . \\
00\end{array}$ & $\begin{array}{l}1020.9 \\
3\end{array}$ & $\begin{array}{l}15.6 \\
27\end{array}$ & 15.6 & 22.817 & 0.59 & 37.828 & $\begin{array}{l}6.87 \\
9 \\
\end{array}$ & $\begin{array}{l}14.7 \\
84\end{array}$ & 7.446 \\
\hline & Tail & $\begin{array}{l}2103 . \\
667\end{array}$ & $\begin{array}{l}1700 . \\
663\end{array}$ & $\begin{array}{l}2342 . \\
00\end{array}$ & $\begin{array}{l}1303 . \\
061\end{array}$ & $\begin{array}{l}2266 . \\
667\end{array}$ & $\begin{array}{l}1301.2 \\
71\end{array}$ & $\begin{array}{l}16.9 \\
72\end{array}$ & $\begin{array}{l}14.6 \\
3\end{array}$ & 19.357 & 4.80 & 18.777 & $\begin{array}{l}11.8 \\
30 \\
\end{array}$ & $\begin{array}{l}15.9 \\
12\end{array}$ & 10.72 \\
\hline & $\begin{array}{l}\text { Verti } \\
\text { cal }\end{array}$ & $\begin{array}{l}1028 . \\
00\end{array}$ & $\begin{array}{l}334.4 \\
71 \\
\end{array}$ & $\begin{array}{l}1117 . \\
33\end{array}$ & $\begin{array}{ll}183.4 \\
38 \\
\end{array}$ & $\begin{array}{l}998.3 \\
3 \\
\end{array}$ & $\begin{array}{l}184.08 \\
2 \\
\end{array}$ & $\begin{array}{l}21.3 \\
61 \\
\end{array}$ & $\begin{array}{l}15.0 \\
2 \\
\end{array}$ & 11.396 & 3.156 & 29.434 & $\begin{array}{l}8.04 \\
8 \\
\end{array}$ & $\begin{array}{l}10.0 \\
01 \\
\end{array}$ & $\begin{array}{l}4.379 \\
3 \\
\end{array}$ \\
\hline $\begin{array}{l}\text { Ogo } \\
\text { ja }\end{array}$ & Head & $\begin{array}{l}2569 . \\
667 \\
\end{array}$ & $\begin{array}{l}972.2 \\
08 \\
\end{array}$ & $\begin{array}{l}2688 . \\
00 \\
\end{array}$ & $\begin{array}{l}874.6 \\
64 \\
\end{array}$ & $\begin{array}{l}2562 . \\
000\end{array}$ & $\begin{array}{l}1018.9 \\
85 \\
\end{array}$ & $\begin{array}{l}18.7 \\
45 \\
\end{array}$ & $\begin{array}{l}11.1 \\
31 \\
\end{array}$ & 31.39 & 3.251 & 20.773 & $\begin{array}{l}9.33 \\
7 \\
\end{array}$ & $\begin{array}{l}29.9 \\
64 \\
\end{array}$ & 4.622 \\
\hline & $\begin{array}{l}\text { Midd } \\
\text { le }\end{array}$ & $\begin{array}{l}2831 . \\
000 \\
\end{array}$ & $\begin{array}{l}912.7 \\
96 \\
\end{array}$ & $\begin{array}{l}4094 . \\
667 \\
\end{array}$ & $\begin{array}{l}599.3 \\
67 \\
\end{array}$ & $\begin{array}{l}4094 . \\
667\end{array}$ & $\begin{array}{l}599.36 \\
7 \\
\end{array}$ & $\begin{array}{l}16.9 \\
94 \\
\end{array}$ & $\begin{array}{l}8.46 \\
9 \\
\end{array}$ & 23.148 & 1.703 & 33.007 & $\begin{array}{l}7.42 \\
1 \\
\end{array}$ & $\begin{array}{l}17.1 \\
8 \\
\end{array}$ & 3.674 \\
\hline & Tail & $\begin{array}{l}2619 . \\
333 \\
\end{array}$ & $\begin{array}{l}522.0 \\
50 \\
\end{array}$ & $\begin{array}{l}2624 . \\
333 \\
\end{array}$ & $\begin{array}{l}530.6 \\
8 \\
\end{array}$ & $\begin{array}{l}2611 . \\
000\end{array}$ & $\begin{array}{l}540.93 \\
3 \\
\end{array}$ & $\begin{array}{l}15.4 \\
06 \\
\end{array}$ & $\begin{array}{l}6.51 \\
1 \\
\end{array}$ & 16.507 & 3.834 & 15.674 & $\begin{array}{l}6.92 \\
4 \\
\end{array}$ & $\begin{array}{l}16.4 \\
11 \\
\end{array}$ & 3.674 \\
\hline & $\begin{array}{l}\text { Verti } \\
\text { cal }\end{array}$ & $\begin{array}{l}1505 . \\
333 \\
\end{array}$ & $\begin{array}{l}1505 \\
333\end{array}$ & 1451 & $\begin{array}{l}512.8 \\
11 \\
\end{array}$ & $\begin{array}{l}1451 . \\
000\end{array}$ & $\begin{array}{l}512.81 \\
1 \\
\end{array}$ & $\begin{array}{l}30.6 \\
45 \\
\end{array}$ & $\begin{array}{l}11.4 \\
84\end{array}$ & 14.08 & 2.827 & 33.307 & $\begin{array}{l}9.92 \\
2\end{array}$ & $\begin{array}{l}13.3 \\
46\end{array}$ & 2.728 \\
\hline
\end{tabular}

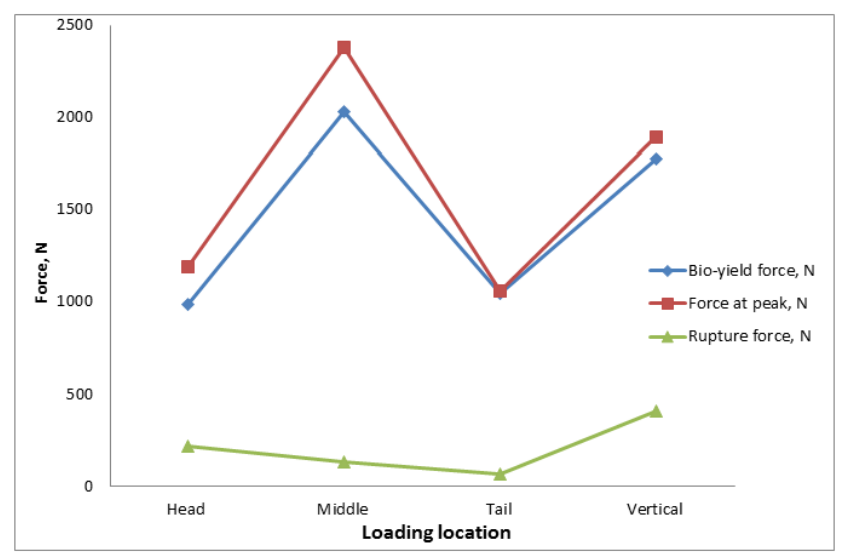

Fig-3: Effect of loading location on forces in Agbo-yian yam tuber

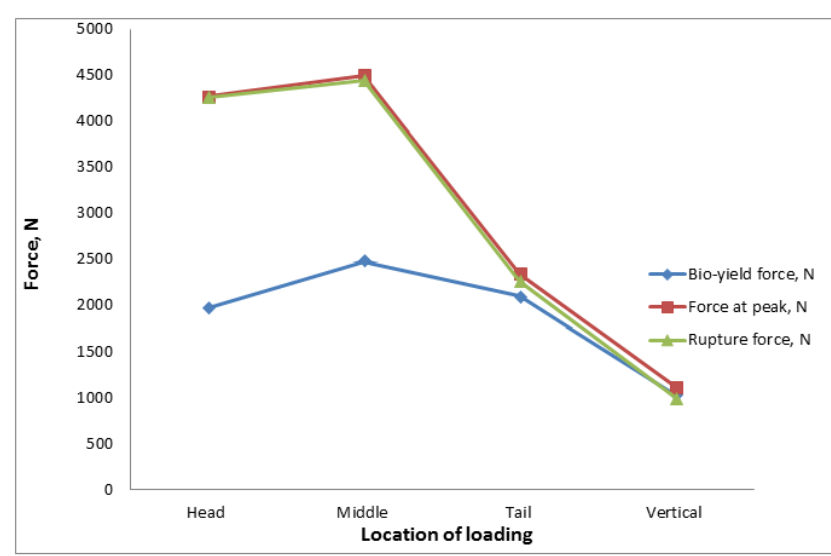

Fig-4: Effect of loading location on forces in Gbangu yam tuber

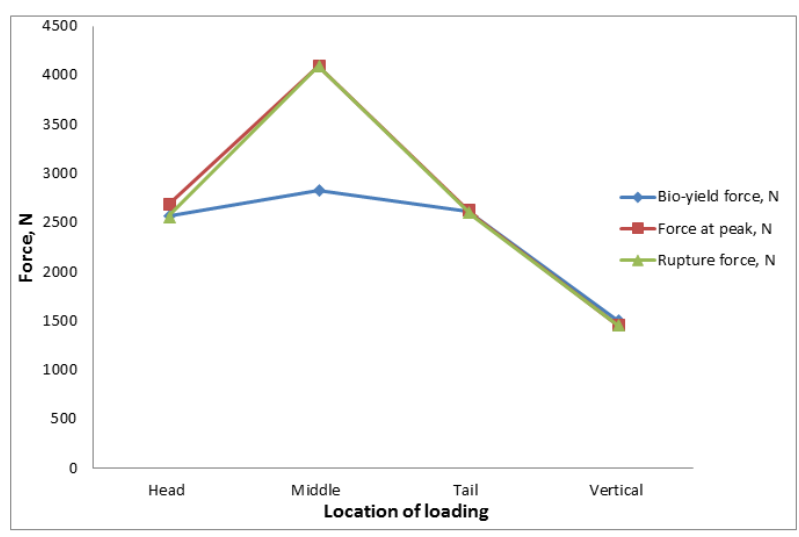

Fig-5: Effect of loading location on forces in Ogoja yam tuber

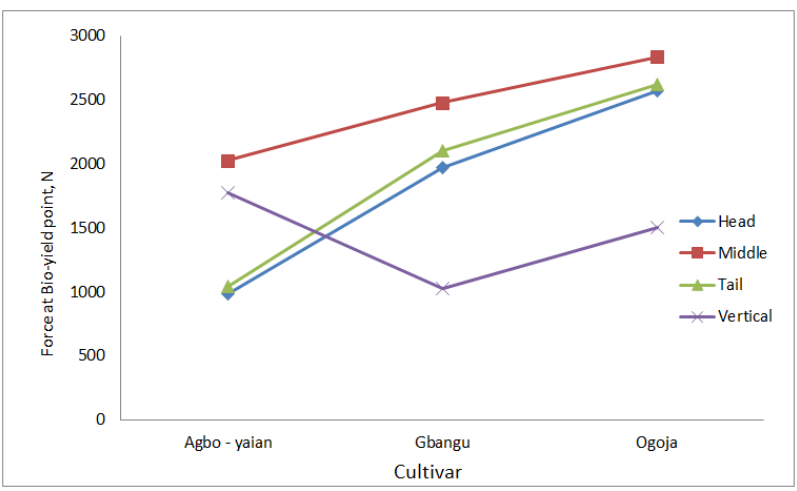

Fig-6: Effect of loading location on forces in three yam cultivars

\section{CONCLUSIONS}

This study focused on the mechanical properties of three different economically promising cultivars of intact yam tubers as affected by location of 
ljabo et al., Saudi J Eng Technol, Nov. 2019; 4(11): 447-451

loading. The results of the study showed that the force at bio-yield point, force at peak point, force at breaking point, and energy at bio-yield point during compression test in general is significantly higher in the middle of the tuber than other locations. The value for bio-yield force range from $1059 \mathrm{~N}$ for Agbo-yian to 4,500 $\mathrm{N}$ for Gbangu. So for safe stacking of Dioscoreaalata in containers and stacks $1059 \mathrm{~N}$ is safe while for Dioscorearotundata 4,500 N would be adequate. Energy follow the same pattern as forces.

\section{REFERENCES}

1. Jimoh, K. O., \& Olatidoye, O. P. (2009). Evaluation of physicochemical and rheological characteristics of soybean fortified yam flour. Journal of Applied Biosciences, 13, 703706.

2. Babalola, M., \& Oyenuga, V. A (2001). Value of Yam (Dioscoreaspp.) in Nigeria Food and Feeding Stuff, Ibadan.University Press, Ibadan, Nigeria. 110-114.

3. Roudaut, G., Maglione, M., van Dusschoten, D., \& Le Meste, M. (1999). Molecular mobility in glassy bread: a multispectroscopy approach. Cereal chemistry, 76(1), 70-77.
4. Akissoe $\mathrm{N}$, Hounhoui J, Mestres C, Nago M. (2003). How blanching and drying affect the colour and functional characteristics of yam (Dioscoreacayenensis-rotundata) flour. Food Chem. 82: 257-264.

5. Bhandari, M. R., Kawabata, J., \& Kasai, T. (2003). Nutritional evaluation of wild yam (Dioscoreaspp.) tubers of Nepal. Food Chem. 80: 619-623.

6. Armando A., Mar V., \& Maite R. M. (2010). Mechanical and viscoelastic properties of yam. Journal of Texture Studies.

7. Niklas, K. J. (1992). Plant biomechanics: An engineering approach to plant form and function. The University of Chicago Press, Chicago, US. 263-270.

8. Taylor, S. E., Buffington, D. E., Collier, R. J., \& DeLorenzo, M. A. (1986). Evaporative Cooling For Dairy Cows In Florida. In Paper-American Society of Agricultural Engineers. ASAE.

9. Judith, B. (2004). Structure and texture of yam (Dioscorea spp.) and processed yam products, A $\mathrm{PhD}$ dissertation submitted to the Swiss Federal Institute of Technology Zurich. 100-152. 